\title{
Protective effect of dietary vitamin $E$ against fungicide copperoxychloride stress on Nile tilapia, Oreochromis niloticus (L.) fingerlings
}

\author{
Mohamed S. Hassaan • Ashraf M. A.-S. Goda • \\ Soaad A. Mahmoud $\cdot$ Safaa I. Tayel
}

Received: 30 May 2013/ Accepted: 1 November 2013/Published online: 22 March 2014

(C) The Author(s) 2014. This article is published with open access at Springerlink.com

\begin{abstract}
A $2 \times 3$ factorial experiment was designed to study the effect of sublethal toxicity of technical grade copperoxychloride, dietary vitamin $\mathrm{E}$ and their interactions on growth performance, some blood parameters, DNA fragmentation and histopathological lesions of Nile tilapia (Oreochromis niloticus). The $96 \mathrm{~h} \mathrm{LC}_{50}$ of copperoxychloride was found to be $129.21 \mathrm{mg} / \mathrm{l}$. Four hundred and fifty fingerlings with an average initial body weight ranged from 1.92 to $2.04 \pm 0.11 \mathrm{~g}$ were randomly distributed equally in six treatments (T1-T6) with each of triplicates. T4, T5 and T6 were exposed to sublethal concentration $0.25 \mathrm{LC}_{50}$ of copperoxychloride. Fish of T1, T2 and T3 fed diet supplemented with different levels of vitamin E $(0,1$ and $2 \mathrm{~g} / \mathrm{kg}$ diet), respectively. While fish of T4, T5 and T6 fed diet supplemented with different levels of vitamin E $(0,1$ and $2 \mathrm{~g} / \mathrm{kg}$ diet), respectively. At the end of the experiment (90 days) the results indicated that fish exposed to $0.25 \mathrm{LC}_{50}$ of copperoxychloride and fed diet with normal level of vitamin $\mathrm{E}$, showed significantly lower values $(P<0.01)$ of all growth and feed utilization parameters, white blood cells and immunoglobulin $\mathrm{M}$, but they showed significantly increased $(P<0.05)$ values of alanine aminotransferase, aspartate aminotransferase, hematocrit, hemoglobin, uric acid and creatinine. Fish fed with varied concentrations of vitamin $\mathrm{E}$ neutralized the toxic effect of copperoxychloride as well as vitamin E, significantly lowered the hematological and biochemical response and enhanced the growth parameters and feed utilization. The toxic effect of copperoxychloride exposure and vitamin E feeding on histopathological alterations of liver and gill of the same studied fish will be taken in concern. The results showed improvement in samples treated with vitamin E. This study suggests that vitamin E can be effectively used to decrease the toxic effect of copperoxychloride on $O$. niloticus and its amelioration through dietary vitamin E supplementation.
\end{abstract}

Keywords Copperoxychloride · Vitamin E · Growth · IgM · DNA fragmentation histopathology · Nile tilapia

M. S. Hassaan ( () ) A. M. A.-S. Goda

Fish Nutrition Research Laboratory, National Institute of Oceanography and Fisheries (NIOF), Cairo, Egypt e-mail: Mohamed_shaban200065@yahoo.com

A. M. A.-S. Goda

e-mail: Goda_ashraf@yahoo.com

S. A. Mahmoud · S. I. Tayel

Fish Diseases Research Laboratory, National Institute of Oceanography and Fisheries (NIOF), Cairo, Egypt

e-mail: Dsoaad_ahmed@hotmail.com

S. I. Tayel

e-mail: dr.safaatayel@yahoo.com 


\section{Introduction}

Today, water quality management faces greater problems than at any time in its history. In addition to natural pollutants, varied contaminants exist in surface waters including multiple chemical compounds and different products of industrial and agricultural revolution. Pollution of the aquatic environment by toxic substances is a cause of growing concern throughout the world, especially in developing countries. The immediate concern is human health and welfare, but the effect of pollution on aquatic organisms also has ecosystem wide consequences (Alam and Maughan 1992). Many of the toxic substances are lipophilic and are not adversely affected by water. These substances accumulate in fish fatty tissues or become protein bound, so it is of importance to know the critical concentration above which humans are affected and the commercial fish species become unsuitable as food (El-Ezaby 1994).

There are many pathways by which insecticides leave their sites of application and distribute throughout the environment and enter the aquatic ecosystem. The major route of insecticides to water ecosystems in urban areas is through rainfall runoff and atmospheric deposition. Another source of water contamination by pesticide is from municipal and industrial dischargers. Most pesticides ultimately find their way into rivers, lakes and ponds (Bagheri 2007; Vryzas et al. 2009) and have been found to be highly toxic to non-target organisms that inhabit natural environments close to agricultural fields. One especially important concern is the large amounts of colloid-size copperoxychloride-based fungicide still freely used in organic farming in Europe (EU directive $\mathrm{CE}$ 889/2008). Copperoxychloride $\left[\mathrm{Cu}_{2} \mathrm{Cl}(\mathrm{OH})_{3}\right]$-based fungicides are in fact widely used against fungal diseases in crops. Copper can enter soil by off-target deposition and foliage wash-off, which lead to its gradual accumulation (Fernández-Calviño et al. 2008; Komárek et al. 2009). The toxicity may be lethal to fish or may lead to stress which in turn causes immuno suppression and susceptibility to secondary infection. The effects of pesticide pollution on non-target organisms in the environment can be studied by detecting changes in organisms at the physiological, biochemical or molecular levels, providing early warning tools in monitoring environment quality (Crane and Maltby 1991; Miren et al. 2000). These sensitive early warning biomarkers can measure the interaction between environmental xenobiotics and biological effects. Inhibition and induction of these biomarkers comprise a good approach to measure potential impacts of pollutants on environmental organisms (Rendon-von Osten et al. 2005). The analysis of hematological and biochemical parameters in fish can contribute to the assessment of the animal's health and also the habitat conditions (Thrall 2004).

Vitamin E ( $\alpha$-tocopherol) is essential for maintaining the normal growth and metabolic function of fish. It acts as a fat-soluble antioxidant in biological membranes and it has been demonstrated to be an essential nutrient for all fish studied (NRC 1993). As well as, its main function is to protect unsaturated fatty acids against free radical-mediated oxidation (Hamre et al. 1998). In addition to that, high dietary supplementation of vitamins E showed positive effects on growth and immune response in channel catfish (Li et al. 1993). Several studies have been carried out on the effect of different fungicides on hematological and biochemical aspects of fish and other aquatic animals, but very few on its amelioration through dietary vitamin E. Considering the commercial value of $O$. niloticus, it is necessary to obtain scientific information about the effect of copperoxychloride on $O$. niloticus to improve risk-assessment studies and its attenuation with the help of dietary vitamin E. This study aimed to assess the effect of the sublethal concentration of copperoxychloride over a long exposure period (90 days) on growth, hematological, histological and biochemical parameters of $O$. niloticus and its amelioration through a gradient of dietary vitamin $\mathrm{E}$.

\section{Materials and methods}

Fingerlings of Nile tilapia, O. niloticus, were obtained from Abassa, Abo-Hamad, Sharkia Governorate, Egypt. Fish were acclimatized for 2 weeks for the lab condition prior to start the experiment; during this period fish were fed a basal diet containing $30 \%$ crude protein. Chlorine-free tap water was used throughout the experiment. 
Lethal concentration 50 of copperoxychloride

Stock solution of copperoxychloride was prepared by dissolving analytical grade copperoxychloride (from Merck) in distilled water. The lethal concentration $50\left(\mathrm{LC}_{50}\right)$ value of copperoxychloride fungicide was determined in the laboratory starting with range finding test to acute toxicity trials according to Reish and Oshida (1987). Three hundred and fifteen fish were randomly distributed in twenty-one glass aquarium (180 1) and exposed to different concentrations of copperoxychloride $(0,25,50,75,100,125$ and $150 \mathrm{mg} / \mathrm{l})$ in triplicates. The mortality was recorded for $96 \mathrm{~h}$ at regular intervals of $12 \mathrm{~h}$. The $\mathrm{LC}_{50}$ value of copperoxychloride was calculated with the help of probit analysis using SPSS software (SPSS for Windows 14.0; SPSS Inc., Chicago, IL, USA, 2005).

Experimental diet

The basal diet (30.83\% crude protein and 19.39 gross energy $\mathrm{Mj} / \mathrm{kg}$ ) was formulated (Table 1). Vitamin E (DL- $\alpha$-tocopheryl acetate) was supplemented to the basal diet to achieve three levels $(0,1$ and $2 \mathrm{~g} / \mathrm{kg}$ diet). All feed ingredients were mixed thoroughly, and dough was prepared with required amount of water. Then dough was conditioned for $30 \mathrm{~min}$ followed by steaming for $1 \mathrm{~min}$. The dough was pressed through a hand pelletizer $(2 \mathrm{~mm})$. Pellets were sun dried for $48 \mathrm{~h}$ and stored at $4{ }^{\circ} \mathrm{C}$. The chemical composition of the diet was determined according to procedures of AOAC (1990). Dry matter was determined after drying the samples in an oven $\left(105^{\circ} \mathrm{C}\right)$ for $24 \mathrm{~h}$. Ash by incineration at $550{ }^{\circ} \mathrm{C}$ for $12 \mathrm{~h}$. Crude protein was determined by microKjeldhal method, N\% × 6.25 (using Kjeltech autoanalyzer, Model 1030, Tecator, Höganäs, Sweden) and crude fat by Soxhlet extraction with diethyl ether $\left(40-60{ }^{\circ} \mathrm{C}\right)$.

Experimental design and procedures

A $2 \times 3$ factorial experiment was designed to study the main effect of fungicide level, vitamin $\mathrm{E}$ and their interaction on growth performance, blood parameters, DNA fragmentation and histopathological lesion of Nile tilapia. Eighteen aquarium $(100 \times 40 \times 50 \mathrm{~cm}, 1801 \mathrm{each})$ triplicates for each treatment were used and

Table 1 Feed ingredients and proximate analysis of the basal diet

\begin{tabular}{|c|c|}
\hline Ingredients & $\%$ \\
\hline Fish meal $(60 \%)$ & 16 \\
\hline Soybean meal (44 \%) & 40 \\
\hline Yellow corn & 28 \\
\hline Wheat bran & 10 \\
\hline Corn oil & 4 \\
\hline Vit and $\min . \operatorname{mix}^{\mathrm{a}}$ & 2 \\
\hline Total & 100 \\
\hline \multicolumn{2}{|l|}{ Proximate analysis } \\
\hline Dry matter $(\mathrm{DM})$ & 89.56 \\
\hline Crude protein $(\mathrm{CP})$ & 30.83 \\
\hline Ether extract (EE) & 5.79 \\
\hline Ash & 6.16 \\
\hline Nitrogen free extract (NFE) ${ }^{\mathrm{b}}$ & 57.22 \\
\hline$(\text { Gross energy } \mathrm{Mj} / \mathrm{kg} \operatorname{diet})^{\mathrm{c}}$ & 19.39 \\
\hline \multicolumn{2}{|c|}{$\begin{array}{l}\text { Vitamin and mineral mix (per kg of diet): } \mathrm{MnSO}_{4}, 40 \mathrm{mg} ; \mathrm{MgO}, 10 \mathrm{mg} ; \mathrm{K}_{2} \mathrm{SO}_{4}, 40 \mathrm{mg} ; \mathrm{ZnCO}_{3}, 60 \mathrm{mg} \text {; KI, } 0.4 \mathrm{mg} ; \mathrm{CuSO}_{4} \text {, } \\
12 \mathrm{mg} \text {; Ferric citrate, } 250 \mathrm{mg} \text {; } \mathrm{Na}_{2} \mathrm{SeO}_{3}, 0.24 \mathrm{mg} ; \mathrm{Co}, 0.2 \mathrm{mg} \text {; retinol, } 40,000 \mathrm{IU} \text {; cholecalciferol, } 4,000 \mathrm{IU} \text {; } \alpha \text {-tocopheryl ace- } \\
\text { tate, } 400 \mathrm{mg} \text {; menadione, } 12 \mathrm{mg} \text {; thiamine, } 30 \mathrm{mg} \text {; riboflavin, } 40 \mathrm{mg} \text {; pyridoxine, } 30 \mathrm{mg} \text {; cyanocobalamin, } 80 \mathrm{mcg} \text {; nicotinic } \\
\text { acid, } 300 \mathrm{mg} \text {; folic acid, } 10 \mathrm{mg} \text {; biotin, } 3 \mathrm{mg} \text {; pantothenic acid, } 100 \mathrm{mg} \text {; inositol, } 500 \mathrm{mg} \text {; ascorbic acid, } 500 \mathrm{mg} \\
{ }^{\text {b }} \mathrm{NFE}=100 \text { - (CP + EE + Ash) }\end{array}$} \\
\hline
\end{tabular}


were continuously aerated with air pumps. Four hundred and fifty fingerlings with an average initial body weights ranged from 1.92 to $2.04 \pm 0.11 \mathrm{~g}$ were randomly distributed equally in six treatments (T1, T2, T3, $\mathrm{T} 4, \mathrm{~T} 5$ and T6) with each of triplicates. T4, T5 and T6 were exposed to sublethal concentration $0.25 \mathrm{LC}_{50}$ of copperoxychloride $(32.3025 \mathrm{mg} / \mathrm{l})$ and fed diet supplemented with different level of vitamin E $(0,1 \mathrm{and} 2 \mathrm{~g} / \mathrm{kg}$ diet), respectively. Fish in T1, T2 and T3 fed diet supplemented with different level of vitamin E (0, 1 and $2 \mathrm{~g} /$ $\mathrm{kg}$ diet) respectively. Fish were fed to satiation, three times a day (09:00, 12:00 and 16:00 h), 6 days a week for 90 days.

Water samples for chemical analysis were monitored weekly during the experimental period. Dissolved oxygen and temperature were measured on site with a YSI model 58 oxygen meter (Yellow Spring Instrument Co., Yellow Springs, OH, USA). Total ammonia was measured using DREL/2 HACH kits (HACH Co., Loveland, Co. USA). pH was measured using a pH meter (Digital Mini-pH Meter, model 55, Fisher Scientific, USA). Total alkalinity and total hardness were measured by titration as described by Boyd (1984).

Growth performance and feed utilization indices

At the end of the experiment fish were collected and weighed. The different parameters of growth and feed utilization were calculated as follows:

Weight gain $(\mathrm{WG}) \mathrm{g}=$ Final body weight $(\mathrm{FBW}) \mathrm{g}-$ Initial body weight $(\mathrm{IBW}) \mathrm{g}$.

Specific growth rate $(\mathrm{SGR})=[(\mathrm{LnW} 2-\mathrm{LnW} 1) / T] \times 100$,

where: $\mathrm{Ln}=$ the natural $\log ; \mathrm{W} 2=\mathrm{FBW}$ at $\mathrm{T} 2(\mathrm{~g}) ; \mathrm{W} 1=\mathrm{IBW}$ at $\mathrm{T} 1(\mathrm{~g}) ; T=$ period of the experimental study, T2-T1 (days).

Survival rate $(\mathrm{SR} \%)=[($ total number of fish - dead number of fish $) /$ total number of fish $] \times 100$.

Feed conversion ratio $(\mathrm{FCR})=$ Feed intake $(\mathrm{FI}) \mathrm{g} / \mathrm{WG} \mathrm{g}$.

Protein efficiency ratio $(\mathrm{PER})=\mathrm{WG} \mathrm{g} /$ crude protein intake $(\mathrm{g})$.

Hematological and biochemical parameters

At the end of the experiment blood samples were collected from the caudal vein of fish of all treatments and were divided into two portions. The first portion was collected with anticoagulant $10 \%$ EDTA (ethylenediaminetetraacetate) to measure hematocrit $(\mathrm{Ht})$, hemoglobin $(\mathrm{Hb})$ and white blood cells (WBCs). Ht was determined as described by Reitman and Frankel (1957), hemoglobin (Hb) was determined by the hemoglobin kits which is a standardized procedure of the cyanomet hemoglobin method as well as the total count of white blood cells (WBCs) was carried out by the indirect method (Martins et al. 2004). The second portion of the blood sample was allowed to clot overnight at $4{ }^{\circ} \mathrm{C}$, centrifuged at 3,000 rpm for $10 \mathrm{~min}$. The non-hemolysed serum was collected and stored at $-20^{\circ} \mathrm{C}$ until use. Levels of serum aspartate aminotransferase (AST), alanine aminotransferase (ALT) according the method described by Reitman and Frankel (1957) and serum creatinine was measured by calorimetric method and enzymatic determination methods as described by Henry (1974).

Serum total immunoglobulin M (IgM) levels were measured by an Enzyme-Linked Immunosorbent Assay (ELISA) using a kit (Cusabio, Wuhan, Hubei, China).

DNA fragmentation

DNA fragmentation was determined using Pernadones methods (Pernadones et al. 1993): liver tissues were dissociated in $400 \mu \mathrm{l}$ hypotonic lysis buffer (0.2\%Triton X-100, $10 \mathrm{mM}$ Tris and $1 \mathrm{~m} \mathrm{MEDTA,} \mathrm{pH} \mathrm{8)} \mathrm{and}$ centrifuged $15 \mathrm{~min}$ at $13,800 \times g$. The supernatant $(\mathrm{SN})$ containing small DNA fragments was separated immediately as well as the pellet containing large pieces of DNA and cell debris was used for the 
diphenylamine assay (DPA). DPA reaction: perchloric acid $(0.5 \mathrm{M})$ was added to the pellets containing uncut DNA (resuspended with $200 \mu$ of hypotonic lysis buffer) and the SN followed by 2 volume of a solution containing (0.088 M DPA, $98 \% \mathrm{v} / \mathrm{v}$ glacial acetic acid, $1.5 \% \mathrm{v} / \mathrm{v}$ sulfuric acid and $0.5 \% \mathrm{v} / \mathrm{v}$ of $1.6 \%$ of acetaldehyde solution). The samples were stored at $4{ }^{\circ} \mathrm{C}$ for $48 \mathrm{~h}$. The colorimetric reaction was quantitated spectrophotometrically at $575 \mathrm{~nm}$ optical density (OD) using an ELISA reader (SLT Labinstruments A-5082, Austria). The percentage of DNA fragmentation was expressed by the formula:

$$
\% \text { DNA }=100 \times \frac{\text { OD SN }}{\text { OD SN }+ \text { OD pellet }} .
$$

Histopathological studies

Liver and gill samples of the same collected fish were carefully removed and fixed in $10 \%$ formalin, dehydrated in ascending grades of alcohol and cleared in xylene. The fixed tissues were embedded in paraffin wax and sectioned into five micrometers in thickness by Euromex Holland microtome. Section was stained according to Harris hematoxylin and eosin method. Consequently, these sections were examined microscopically and their photos were taken using a microscopic camera (Bernet et al. 1999).

Statistical analysis

All data were analyzed by software SAS (Statistical Analysis System 1993) ANOVA procedure. One-way analysis of variance (One-way ANOVA) was used to determine whether significant variation existed between the treatments. Two-way ANOVA was used for analyzing the individual effects of fungicide levels and vitamin E, and the interaction between them. Duncan's multiple range test (Duncan 1955) was used to compare differences among individual means. All differences were considered significant at $P<0.05$. All percentage data were arc-sin transformed prior to analysis (Zar 1984); however, data are presented untransformed to facilitate comparisons.

\section{Results}

In the present study, the $96 \mathrm{~h} \mathrm{LC}_{50}$ of copperoxychloride was found to be $129.21 \mathrm{mg} / \mathrm{l}$.

During the 12 weeks the water temperature was $26.17 \pm 0.8^{\circ} \mathrm{C}$ : dissolved oxygen, $5.6 \pm 0.8 \mathrm{mg} / \mathrm{l}$ : total ammonia, $0.18 \pm 0.12 \mathrm{mg} / \mathrm{l}$ and $\mathrm{pH} 8.52 \pm 0.3$.

Effect of vitamin E (vit.E) and copperoxychloride and their interactions on growth performance and feed utilization of treatment groups are presented in Table 2. Results indicates that FBW, WG, SGR, FI and PER were significantly higher $(P<0.05)$ in T2 and T3 compared to all treatments. The significant $(P<0.05)$ value lowest of FBW, WG, SGR, FI and survival rate (SR) were recorded in T4, whereas T5, which was exposed to $0.25 \mathrm{LC}_{50}$ copperoxychloride and fed diet supplemented with $1 \mathrm{~g}$ vit.E/kg showed similarity with $\mathrm{T} 1 \mathrm{in} \mathrm{FBW}$, WG, SGR and SR and the differences among treatments were not significant $(P>0.05)$. In the same respect, FCR was significantly $(P<0.01)$ lowest (better) in T2 and T3 in comparison to the other groups.

The changes in some hematological and some biochemical parameters of Nile tilapia were affected significantly $(P<0.05)$ by sublethal fungicide level and vit.E and their interactions (Table 3$)$. AST, ALT, uric acid and creatinine were significantly higher $(P<0.01)$ in fish T4 which was exposed to $0.25 \mathrm{LC}_{50}$ and fed diet unsupplemented with vitamin $\mathrm{E}$ in comparison to the other treatments, but the lowest was one obtained by fish of T3 which were not exposed to fungicide and fed $2 \mathrm{~g}$ vit.E/ $\mathrm{kg}$ diet. Moreover, fish of T6 which were exposed to $0.25 \mathrm{LC}_{50}$ of copperoxychloride and fed diet supplemented with $2 \mathrm{~g}$ vitamin $\mathrm{E} / \mathrm{kg}$ showed similarity with $\mathrm{T} 1$ in respect to values of AST, uric acid and creatinine. Ht and $\mathrm{Hb}$ showed the opposite trend of biochemical parameters, with the highest $\mathrm{Ht}$ and $\mathrm{Hb}$ values recorded by fish of $\mathrm{T} 3$ and the lowest one obtained by fish of T4.

WBCs and IgM were significantly $(P<0.05)$ affected by sublethal fungicide and level of supplemented vitamin $\mathrm{E}$ and their interactions (Table 4). High WBCs and IgM were recorded in T2 and T3, but the lowest values of WBCs and $\mathrm{IgM}$ were recorded by fish of $\mathrm{T} 4$ which exposed to $0.25 \mathrm{LC}_{50}$ of copperoxychloride. 
Table 2 Effect of fungicide and vitamin E-supplement levels and their interactions on body weight, weight gain, specific growth rate, survival rate, feed intake, feed conversion ratio and protein efficiency ratio of $O$. niloticus

\begin{tabular}{|c|c|c|c|c|c|c|c|c|c|c|}
\hline \multirow[t]{2}{*}{$\mathrm{T}$} & \multirow[t]{2}{*}{ Fungicide } & \multirow[t]{2}{*}{ Vit.E (g/kg diet) } & \multicolumn{2}{|c|}{ Body weight } & \multirow[t]{2}{*}{ WG } & \multirow[t]{2}{*}{ SGR } & \multirow[t]{2}{*}{ FI } & \multirow[t]{2}{*}{ FCR } & \multirow[t]{2}{*}{ PER } & \multirow[t]{2}{*}{$\mathrm{SR} \%$} \\
\hline & & & IBW & $\mathrm{FBW} \pm \mathrm{SE}$ & & & & & & \\
\hline $\mathrm{T} 1$ & 0 & 0 & 1.94 & $19.50 \pm 0.73^{\mathrm{ab}}$ & $17.27^{\mathrm{b}}$ & $2.41 \mathrm{c}$ & $30.93 b$ & $1.79^{\mathrm{ab}}$ & $1.85 \mathrm{~b}$ & $91.66^{\mathrm{a}}$ \\
\hline $\mathrm{T} 2$ & 0 & 1 & 2.04 & $21.94 \pm 0.73^{\mathrm{a}}$ & $19.73^{\mathrm{a}}$ & $2.55 \mathrm{~b}$ & $31.48 \mathrm{a}$ & $1.62^{\mathrm{c}}$ & $2.05 \mathrm{a}$ & $93.33^{\mathrm{a}}$ \\
\hline $\mathrm{T} 3$ & 0 & 2 & 1.98 & $21.20 \pm 0.71^{\mathrm{a}}$ & $20.11^{\mathrm{a}}$ & $2.62 \mathrm{a}$ & $32.15 \mathrm{a}$ & $1.60^{\mathrm{c}}$ & $2.08 \mathrm{a}$ & $95.00^{\mathrm{a}}$ \\
\hline $\mathrm{T} 4$ & 0.25 & 0 & 1.96 & $18.56 \pm 0.75^{\mathrm{b}}$ & $16.20^{\mathrm{d}}$ & $2.29 \mathrm{~d}$ & $29.15 d$ & $1.82^{\mathrm{a}}$ & $1.85 b$ & $85.00^{\mathrm{b}}$ \\
\hline T5 & 0.25 & 1 & 1.92 & $19.66 \pm 0.73^{\mathrm{ab}}$ & $17.45^{\mathrm{b}}$ & $2.43 \mathrm{c}$ & $29.72 \mathrm{c}$ & $1.77^{\mathrm{ab}}$ & $1.88 \mathrm{~b}$ & $91.66^{\mathrm{a}}$ \\
\hline T6 & 0.25 & 2 & 1.95 & $18.83 \pm 0.71^{\mathrm{b}}$ & $16.76^{\mathrm{c}}$ & $2.45 \mathrm{c}$ & $29.77 \mathrm{c}$ & $1.71^{\mathrm{b}}$ & $1.95 \mathrm{~b}$ & $92.50^{\mathrm{a}}$ \\
\hline \multicolumn{3}{|c|}{ Pooled SE } & 0.11 & & 0.163 & 0.021 & 0.273 & 0.028 & 0.030 & 1.29 \\
\hline \multicolumn{11}{|c|}{ Two-way ANOVA ( $P$ value) } \\
\hline \multicolumn{3}{|c|}{ Fungicide } & & 0.0030 & 0.001 & 0.001 & 0.001 & 0.025 & 0.0241 & 0.0054 \\
\hline \multicolumn{3}{|c|}{ Vitamin E } & & 0.0336 & 0.001 & 0.001 & 0.0001 & 0.043 & 0.0471 & 0.0056 \\
\hline \multicolumn{3}{|c|}{ Fungicide $\times$ Vit.E } & & 0.0004 & 0.001 & 0.001 & 0.0001 & 0.018 & 0.0189 & 0.0074 \\
\hline
\end{tabular}

Data are presented as mean \pm standard error $(\mathrm{SE})$. Means followed by different letters in each column are significantly $(P<0.05)$ different

$I B W$ initial body weight (g), FBW final body weight (g), WG weight gain, $S G R$ specific growth rate, $S R$ survival rate, $F I$ feed intake (g), FCR feed conversion ratio, PER protein efficiency ratio

Table 3 Effect of fungicide and vitamin E-supplement levels and their interactions on alanine aminotransferase, aspartate aminotransferase, hematocrit, hemoglobin, uric acid and creatinine levels of $O$. niloticus

\begin{tabular}{|c|c|c|c|c|c|c|c|c|}
\hline $\mathrm{T}$ & Fungicide & $\begin{array}{l}\text { Vit.E } \\
\text { (g/kg diet) }\end{array}$ & $\begin{array}{l}\text { ALT } \\
(\mathrm{IU} / \mathrm{l})\end{array}$ & $\begin{array}{l}\mathrm{AST} \\
(\mathrm{IU} / \mathrm{l})\end{array}$ & $\mathrm{Ht}(\%)$ & $\begin{array}{l}\mathrm{Hb} \\
(\mathrm{g} / \mathrm{dl})\end{array}$ & $\begin{array}{l}\text { Uric acid } \\
(\mathrm{mg} / 100 \mathrm{ml})\end{array}$ & $\begin{array}{l}\text { Creatinine } \\
(\mathrm{mg} / 100 \mathrm{ml})\end{array}$ \\
\hline $\mathrm{T} 1$ & 0 & 0 & $19.96^{\mathrm{d}}$ & $93.62^{\mathrm{b}}$ & $21.38^{\mathrm{ab}}$ & $11.33^{\mathrm{bc}}$ & $11.13^{\mathrm{cd}}$ & $0.657^{\mathrm{c}}$ \\
\hline $\mathrm{T} 2$ & 0 & 1 & $20.17^{\mathrm{d}}$ & $93.67^{\mathrm{b}}$ & $22.33^{\mathrm{a}}$ & $11.48^{\mathrm{ab}}$ & $11.03^{\mathrm{cd}}$ & $0.623^{\mathrm{c}}$ \\
\hline $\mathrm{T} 3$ & 0 & 2 & $19.89^{\mathrm{d}}$ & $92.10^{\mathrm{b}}$ & $22.81^{\mathrm{a}}$ & $11.70^{\mathrm{a}}$ & $10.80^{\mathrm{d}}$ & $0.617^{\mathrm{d}}$ \\
\hline $\mathrm{T} 4$ & 0.25 & 0 & $47.94^{\mathrm{a}}$ & $99.02^{\mathrm{a}}$ & $19.13^{\mathrm{c}}$ & $10.02^{\mathrm{d}}$ & $16.11^{\mathrm{a}}$ & $0.920^{\mathrm{a}}$ \\
\hline T5 & 0.25 & 1 & $33.88^{\mathrm{b}}$ & $95.51^{\mathrm{ab}}$ & $20.29^{\mathrm{bc}}$ & $11.10^{\mathrm{c}}$ & $12.24^{\mathrm{b}}$ & $0.810^{\mathrm{b}}$ \\
\hline T6 & 0.25 & 2 & $32.55^{\mathrm{c}}$ & $94.69^{\mathrm{b}}$ & $21.27^{\mathrm{ab}}$ & $11.13^{\mathrm{c}}$ & $11.87^{\mathrm{bc}}$ & $0.660^{\mathrm{c}}$ \\
\hline \multicolumn{3}{|c|}{ Pooled SE } & 0.328 & 1.14 & 0.477 & 0.086 & 0.263 & 0.012 \\
\hline \multicolumn{9}{|c|}{ Two-way ANOVA ( $P$ value $)$} \\
\hline \multicolumn{3}{|c|}{ Fungicide } & 0.0001 & 0.0055 & 0.0005 & 0.0001 & 0.0001 & 0.0001 \\
\hline \multicolumn{3}{|c|}{ Vit.E. } & 0.0001 & 0.0078 & 0.0122 & 0.0001 & 0.0001 & 0.0001 \\
\hline \multicolumn{3}{|c|}{ Fungicide $\times$ Vit.E } & 0.0001 & 0.0230 & 0.0030 & 0.0001 & 0.0001 & 0.0001 \\
\hline
\end{tabular}

Data are presented as mean \pm standard error $(\mathrm{SE})$. Means followed by different letters in each column are significantly $(P<0.05)$ different

$A L T$ alanine aminotransferase, $A S T$ aspartate aminotransferase, $H t$ hematocrit, $H b$ hemoglobin

Whereas, there were no significant $(P>0.05)$ differences between T5, T6 exposed to $0.25 \mathrm{LC}_{50}$ and fish fed diet supplemented with 1 or $2 \mathrm{~g} / \mathrm{kg}$ diet, respectively.

The DNA fragmentation was significantly $(P<0.05)$ affected by sublethal fungicide and vitamin $\mathrm{E}$ supplementation and their interactions; it was increased significantly with fungicide exposure and a positive trend was shown in diet supplemented with vitamin E. The highest DNA fragmentation was obtained by fish of T4 which were exposed to $0.25 \mathrm{LC}_{50}$ of copperoxychloride and fed diet unsupplemented with vit. E. T5 and T6 showed the same trend of DNA fragments T1 group without any significant differences between T1, T5 and T6.

Liver histology from control and exposed Nile tilapia is briefly illustrated in Fig. 1a-f. In control group, the liver of many samples exhibited a normal architecture and there were no pathological abnormalities, with hepatocytes presenting a homogenous cytoplasm, and a large central or subcentral spherical nucleus, only 
Table 4 Effect of fungicide and vitamin E-supplement levels and their interactions on white blood cells (WBCs), immunoglobulin $\mathrm{M}(\mathrm{IgM})$ and DNA fragmentation of $O$. niloticus

\begin{tabular}{|c|c|c|c|c|c|}
\hline$\overline{\mathrm{T}}$ & Fungicide & Vit.E (g/kg diet) & WBCs $\left(\times 10^{3} \mathrm{~mm}^{-3}\right)$ & $\operatorname{IgM}(\mu \mathrm{g} / \mathrm{ml})$ & DNA fragmentation $(\%)$ \\
\hline $\mathrm{T} 1$ & 0 & 0 & $15.06 \mathrm{~b}$ & $159.79 b$ & $5.57 \mathrm{~b}$ \\
\hline $\mathrm{T} 2$ & 0 & 1 & $16.85 \mathrm{a}$ & $164.41 \mathrm{a}$ & $5.63 b$ \\
\hline $\mathrm{T} 3$ & 0 & 2 & $17.74 \mathrm{a}$ & $165.91 \mathrm{a}$ & $5.39 \mathrm{~b}$ \\
\hline $\mathrm{T} 4$ & 0.25 & 0 & $10.70 \mathrm{c}$ & $143.28 \mathrm{c}$ & $9.68 \mathrm{a}$ \\
\hline T5 & 0.25 & 1 & $15.32 b$ & $159.10 \mathrm{~b}$ & $6.69 b$ \\
\hline T6 & 0.25 & 2 & $15.81 \mathrm{~b}$ & $160.33 b$ & $5.59 \mathrm{~b}$ \\
\hline \multicolumn{3}{|c|}{ Pooled SE } & 0.309 & 0.747 & 0.480 \\
\hline \multicolumn{6}{|c|}{ Two-way ANOVA ( $P$ value) } \\
\hline \multicolumn{3}{|c|}{ Fungicide } & 0.0001 & 0.0001 & 0.0011 \\
\hline \multicolumn{3}{|c|}{ Vit.E. } & 0.0001 & 0.0001 & 0.0035 \\
\hline \multicolumn{3}{|c|}{ Fungicide $\times$ Vit.E } & 0.0001 & 0.0001 & 0.006 \\
\hline
\end{tabular}

Data are presented as mean \pm standard error (SE). Means followed by different letters in each column are significantly $(P<0.05)$ different

some samples showed fatty degeneration (Fig. 1a). The hepatic parenchyma of fish fed a diet supplemented by $1 \mathrm{~g}$ Vit.E showed degeneration (Fig. 1b). While fish fed a diet supplemented by $2 \mathrm{~g}$ vitamin $\mathrm{E}$ showed pyknosis (Fig. 1c). Additionally, O. niloticus exposed to copperoxychloride cleared, hemorrhage in their hepatic parenchyma (Fig. 1d). However, the hepatic parenchyma of fish exposed to copperoxychloride and fed $1 \mathrm{~g}$ vit.E suffer only from focal necrosis (Fig. 1e). Finally, O. niloticus exposed to copperoxychloride and fed $2 \mathrm{~g}$ vit.E showed congestion in blood sinusoid (Fig. 1f).

Gill, histology from control and exposed fish is briefly illustrated in Fig. 2a-f. The gill morphology of the control tilapia was similar to that of other teleost fish species (Wilson and Laurent 2002). In fish fed diet with vit.E and not treated with fungicide, the gill was made up of double rows of filaments (primary lamellae) from which arise perpendicularly the lamellae (secondary lamellae). The lamellae are lined by a squamous epithelium composed by pavement and non-differentiated cells. Gill obtained from fish fed diet supplemented with 1 and $2 \mathrm{~g}$ vitamin $\mathrm{E}$ show normal appearance of gill primary and secondary lamellae. On the other hand, only some samples showed cell degeneration (Fig. 2a-c). While fish exposed to copperoxychloride showed hemorrhage in primary lamellae and separation in epithelial cells of secondary lamellae (Fig. 2d). However, fish exposed to copperoxychloride and fed $1 \mathrm{~g}$ vit.E suffer from necrosis and curling in their gill epithelial cells of secondary lamellae (Fig. 2e). Finally, fish exposed to copperoxychloride and fed $2 \mathrm{~g}$ vit.E showed separation in epithelial cells of secondary lamellae (Fig. 2f).

\section{Discussion}

The obtained result indicated a significant decrease in the growth performance of $O$. niloticus after exposure to sublethal dose of copperoxychloride fungicide. In Channa punctatus the most important factors decreasing growth consist of disorder in feeding behaviors, decrease in feeding rate, dysfunction in metabolism process and waste of energy to overcome the stress caused by insecticide exposure (Tripathi et al. 2003). The reduced growth is in agreement with the results of Sweilum (2006) who found that the growth of O. niloticus decreased due to the exposure to dimethoate $(20,10$ and $5 \mathrm{mg} / \mathrm{l})$ and malathion $(2,1$ and $0.5 \mathrm{mg} / \mathrm{l})$. Similarly, Mousa et al. (2005) reported that Nile tilapia exposed to basegran herbicide at field concentration $(0.004 \mathrm{mg} / \mathrm{l}=1 /$ $\left.100 \mathrm{LC}_{50}\right)$ and at half of field concentration showed significant $(P<0.05)$ reduction in growth with increasing the level of pesticide compared with the control fish. Moreover, Jiann and Chia (2001) revealed that the mortality rates of Penaeus monodon juveniles following exposure to 0 (control), 0.45, 0.90, 1.80 and $4.50 \mathrm{mg} /$ 1 copper concentrations after 30 days were $0,5.6,22.2$ and $55.6 \%$, respectively.

Irrespective of copperoxychloride levels, the diet supplemented with 1 and $2 \mathrm{~g}$ vit.E/kg diet had better results of growth performance and feed utilization than those of fish fed diets unsupplemented with vit.E. 

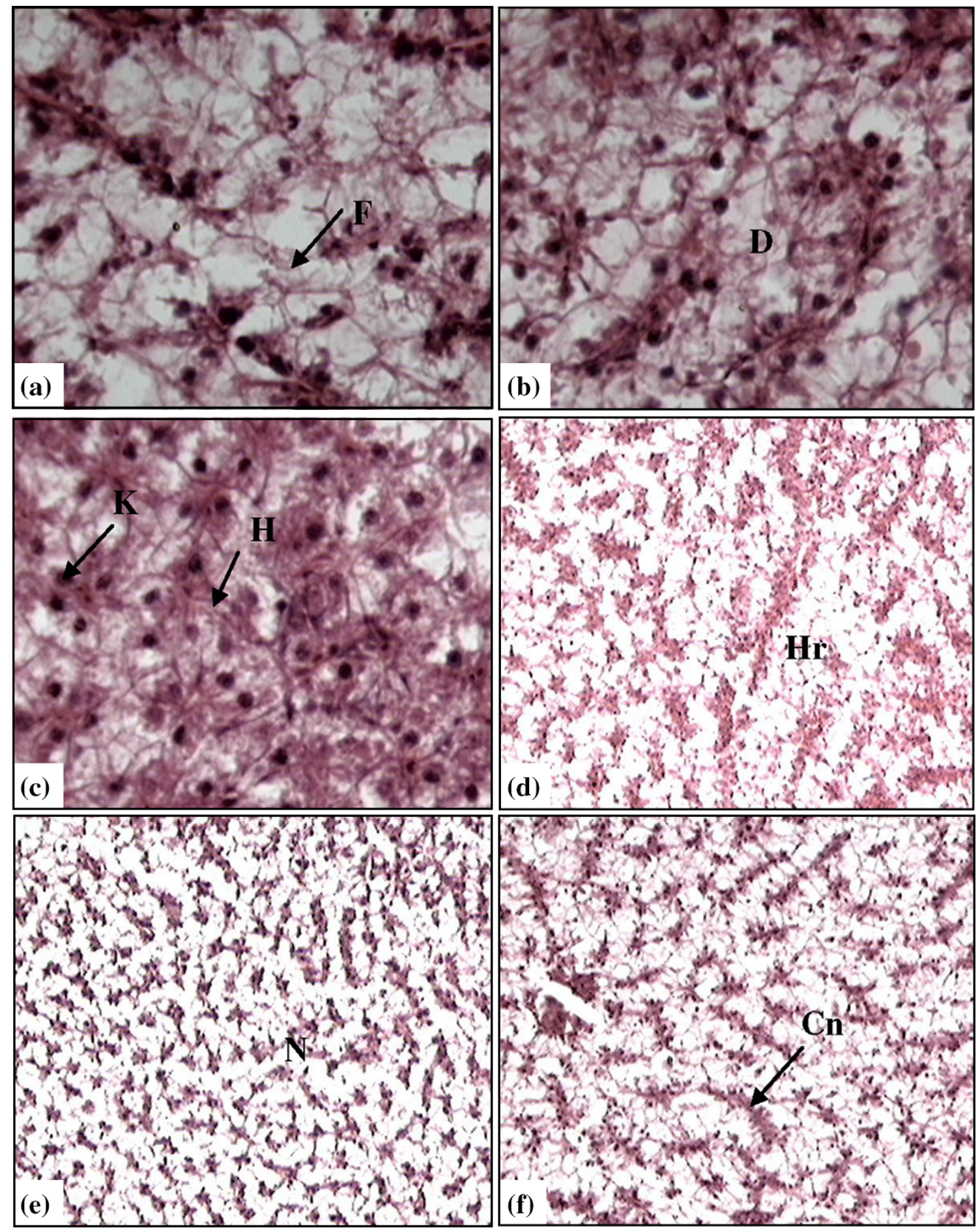

Fig. 1 Liver sections of $O$. niloticus fish stained with H\&E. a Fatty degeneration (normal), b degeneration (D) (1 g vit.E), c hepatic cell $(\mathrm{H})$ and pyknosis $(\mathrm{K})$ (2 $\mathrm{g}$ vit.E), d severe hemorrhage (Hr) (copperoxychloride), e focal necrosis (N) (copperoxychloride and $1 \mathrm{~g}$ vit.E), $\mathbf{f}$ congestion in blood sinusoid $(\mathrm{Cn})$ (copperoxychloride and $2 \mathrm{~g}$ vit.E)

These results are similar to those reported by, Kim et al. (2003) who mentioned that Nile tilapia fed diet supplemented with $150 \mathrm{mg}$ vit.E had significantly $(P<0.05)$ higher growth performance than those fed the control diet. Also, Galaz et al. (2010) noted that dietary inclusion of vit.E significantly influenced growth performance and feed utilization of the juvenile parrot fish (Oplegnathus fasciatus). Up to $38 \mathrm{mg}$ vit.E/kg diet 

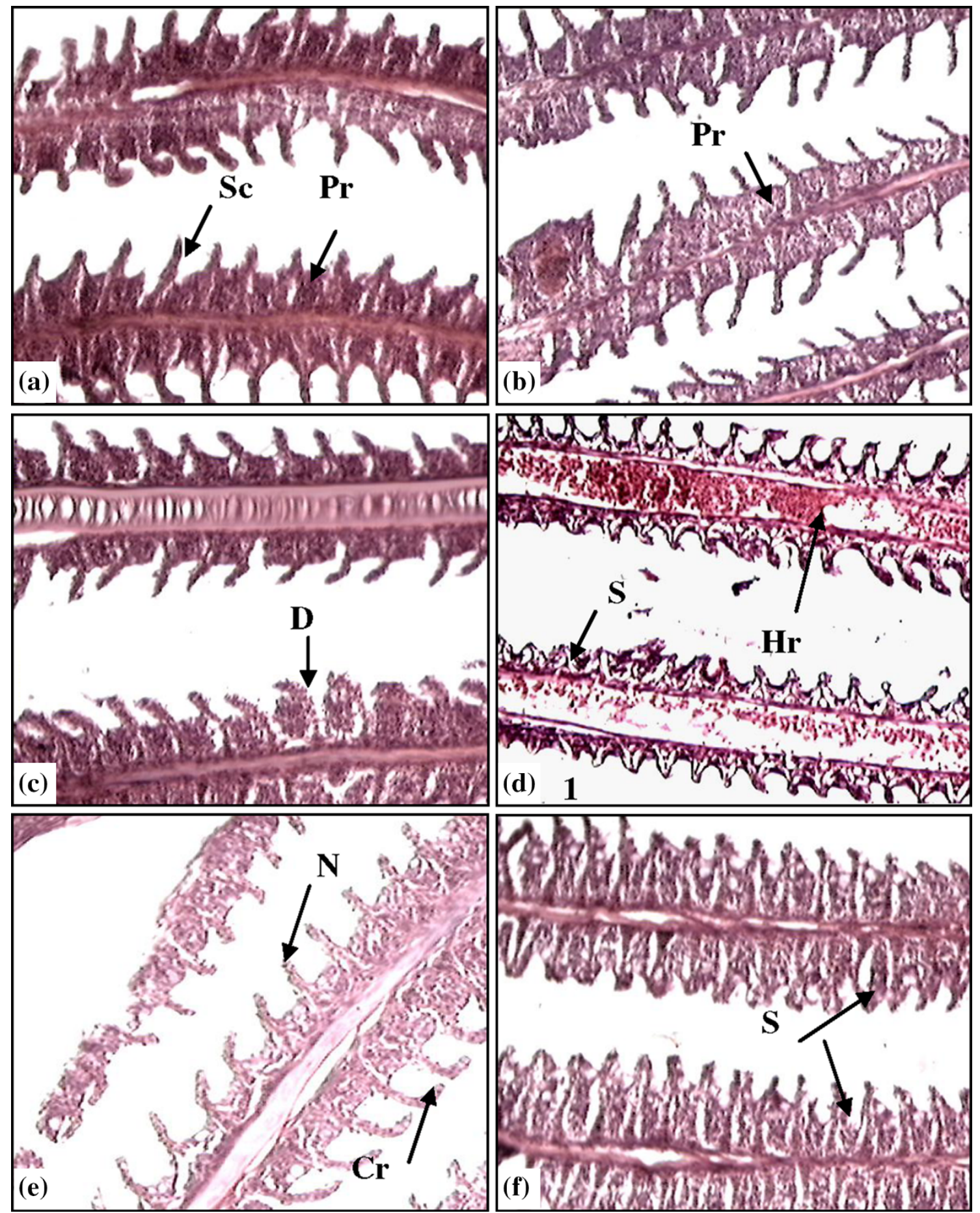

Fig. 2 Gill longitudinal section of $O$. niloticus fish stained with H\&E. a Primary lamellae (Pr) and secondary lamellae (Sc) (normal). b Primary lamellae (Pr) (1 g vit.E). c Degeneration (D) in secondary lamellae ( $2 \mathrm{~g}$ vit.E). d Hemorrhage (Hr) in primary lamellae and separation $(\mathrm{S})$ in epithelial cells of secondary lamellae (copperoxychloride). e Necrosis $(\mathrm{N})$ and $\mathrm{curling}(\mathrm{Cr})$ in epithelial cells of secondary lamellae (1 g vit.E and copperoxychloride). f Separation (S) in epithelial cells of secondary lamellae ( $2 \mathrm{~g}$ vit.E and copperoxychloride)

and beyond that level no further increase was observed. The same pattern was also noticed for protein efficiency ratio (PER). Lower feed conversion ratio (FCR) was observed in fish fed the $38 \mathrm{mg}$ vit.E/kg diet. Similarly, Sau et al. (2004) reported that, in rohu fry fed five semi-purified diets supplemented with 0, 50, 100, 
150, $200 \mathrm{mg}$ vit.E/kg diet as DL- $\alpha$-tocopheryl acetate, fish fed diets containing less than $100 \mathrm{mg}$ supplemental vit.E/kg diet had significantly $(P<0.05)$ reduced WG, FER and other nutritional indices compared to those fed diets supplemented with vit.E at $100-200 \mathrm{mg} / \mathrm{kg}$ diet. Values of PER were significantly higher in $115.70 \mathrm{mg} / \mathrm{kg}$ diet vs other groups and lowest in control group (without supplementation of vit.E), at the last, FCR was observed in fish fed the diet supplemented with 100, 150 and $200 \mathrm{mg} / \mathrm{kg}$ diets. Furones et al. (1992) observed that in rainbow trout (Oncorhynchus mykiss) fed diets containing 7, 86 or $806 \mathrm{mg}$ vit.E/ $\mathrm{kg}$ diet for 22 weeks and exposed to virulent Yersinia ruckeri by bath or injection, mortalities were always least among those fed the highest concentration of vit.E. Similar trend was observed by Abdel-Tawab (1999) and Sweilum (2000) with Mugil cephalus and O. niloticus, respectively.

The present study indicated slight differences between fish untreated with fungicide and fed normal level of vit.E and fish exposed to $0.25 \mathrm{LC}_{50}$ copperoxychloride and fed 1 or $2 \mathrm{~g}$ vit.E. This indicates that 1 or $2 \mathrm{mg}$ vit.E $/ \mathrm{kg}$ diet of fish minimized the toxic effect of copperoxychloride. The outcomes of the present study came in agreement with those of Mourente et al. (2002) that recorded that growth and survival of sea bream were relatively unaffected by heavy metals in a vit.E-supplemented diet. Also, Steven (2002) recorded growth depression in fish fed a $\mathrm{Pb}$-supplemented diet was prevented with the supplementation of antioxidants.

Alanine aminotransferase (ALT) and aspartate aminotransferase (AST) enzymes are liver enzymes and a kind of transferase. They have the function of transferring amino group from alpha-amino acids to alpha-keto acids. Large amount of ALT and AST is released into blood mostly during liver cell damage. Thus, detection of serum level of ALT and AST tells monitored liver cell damage (Soltan et al. 2008). The results of the present study indicated that ALT and AST activities were increased significantly $(P<0.05)$ with exposure to sublethal dose of copperoxychloride fungicide. The increase of ALT and AST activities in fish exposed to copperoxychloride level might be due to dysfunction and hepatocellular damage of liver. These results are in accordance with those reported by many investigators. Hashim and Zaki (2005) reported that catfish exposed to fungicide Dithane in dose of $0.5 \mathrm{ppm} / 1$ for 30 days showed an increase $(P<0.05)$ in serum ALT and AST activities compared with the control. Jiraungkoorskul et al. (2003) indicated that $O$. niloticus exposed for 3 months to 5 and 15 ppm of the commercial herbicide Roundup showed significant $(P<0.05)$ increase in plasma ALT and AST activities. Also, Ramzy (2009) indicated that ALT and AST enzyme activities of Nile tilapia were significantly $(P<0.05)$ increased throughout the whole experimental period of acute exposure and chronic exposure $\left(1 / 10 \mathrm{LC}_{50}\right)$ to selecoron insecticide. The AST activity of fish exposed to $0.25 \mathrm{LC} 50$ of copperoxychloride increased in the present study; however, amelioration in the AST activity of fish exposed to fungicide and fed high level of vit.E could be the consequence of vit.E increasing the anti-stress ability. These results confirmed those of Metwally et al. (2002) who reported that in O. niloticus receiving $500 \mathrm{mg} \mathrm{CuSO} / \mathrm{kg}$ diet and fed diets supplemented with $(0,250,500,750$ and $1,000 \mathrm{mg}$ vit.E/kg diet), the activity of liver function enzymes AST and ALT increased significantly in the blood serum of specimens fed the diet containing $500 \mathrm{mg} \mathrm{Cu} / \mathrm{kg}$ diet compared to the control diet.

The present study indicated a significant decrease in $\mathrm{Ht}$ and $\mathrm{Hb}$ after exposure to a sublethal dose of copperoxychloride. These results may be due to the inhibition of erythropoiesis, hemosynthesis, osmoregulatory dysfunction or due to increased rate of erythrocyte destruction in the hematopoietic organ, as came in Catla catla exposed to deltamethrin as recorded by Vani et al. (2011). Also, Svobodova et al. (2003) reported significantly lower values of red blood cells and $\mathrm{Hb}$ in Cyprinus carpio after acute exposure to deltamethrin. The reduction in hemoglobin might be due to the inhibition of erythropoiesis, hemosynthesis, osmoregulatory dysfunction or due to increased rate of erythrocyte destruction in the hematopoietic organ, as reported in Cyprinus carpio exposed to endosulfan (Jenkins et al. 2003). Whereas fish exposed to 0.50 and fed diet supplemented with 1 or $2 \mathrm{~g}$ vit.E/ $\mathrm{kg}$ diet showed slightly increased $\mathrm{Ht}$ and $\mathrm{Hb}$ compared to the fish not exposed to fungicide and fed diet with normal level of vit.E, this indicates that supplemented diet with 1 or $2 \mathrm{~g}$ vit.E decreased the toxic effect of copperoxychloride and stimulated immune response to cope up the copperoxychloride stress. In this respect, Wise et al. (1993) reported that susceptibility of red blood cells of channel catfish fingerlings to oxidative hemolysis decreased with increasing levels of dietary $\alpha$-tocopherol acetate.

Serum uric acid and creatinine can be used as a rough index of the glomerular filtration rate (Maita et al. 1984). Low values of creatinine and uric acid have no significant, but increased values cause several disturbances in the kidney (Maxine and Benjamine 1985). The increased uric acid and creatinine activities were shown by fish exposed to copperoxychloride. The obtained results are in agreement with those obtained by Abdel-Tawwab et al. (2007) who reported that $O$. niloticus exposed to copper concentrations 0.503 or $1.25 \mathrm{mg}$ 
$\mathrm{Cu}^{2+} / 1$ showed significant $(P<0.05)$ increase in creatinine and uric acid. Also, Hashim and Zaki $(2005)$ reported that catfish exposed to fungicide Dithane at dose of $0.5 \mathrm{ppm} / 1$ for 30 days revealed an increase $(P<0.05)$ in creatinine and uric acid values compared with the control. However, supplemented diet with 1 or $2 \mathrm{~g}$ vit.E/ $\mathrm{kg}$ diet decreased serum uric acid and creatinine activity for fish exposed to $0.25 \mathrm{LC}_{50}$ of copperoxychloride, this might be due to the protective function of vit.E. In partial agreement with our results, Metwally et al. (2002) reported non-significant changes in serum creatinine of $O$. niloticus fed diet containing to vit.E, on the other hand uric acid was significantly increased $(P<0.01)$ in blood serum of $O$. niloticus fed diet containing $500 \mathrm{mg} \mathrm{CuSO} / \mathrm{kg}$ diet compared to group treated with vit.E. Also, Senug et al. (2007) recorded that vit.E appears to provide protection against oxidative stress caused by $\mathrm{Pb}$ toxicity.

The present study showed a significant decrease in WBC counts in fish exhausted by copperoxychloride fungicide; this result may be due to the inhibition of the hemopoietic tissue activity. In agreement with the results in this study, Svoboda et al. (2003) concluded that the changes in leukocyte differential count gave an evidence for decreased level of non-specific immunity in fish after exposure to deltamethrin. O. niloticus exposed to low levels of the organophosphate pesticide chlorpyrifos have significantly lower total pronephros cell counts and depressed macrophage phagocytic ability compared to untreated controls (Holladay et al. 1996). Also, Khoshbavar-Rostami et al. (2006) indicated that great sturgeon (Huso huso) exposed to a longterm sublethal concentration of diazinon showed significantly $(P<0.05)$ lower WBCs and lymphocytes values compared with the control fish group. However, the decrease in WBCs differential count of fish exposed to sublethal levels of the copperoxychloride may be due to the toxicant effect on the fish cellular immunity. Similarly, Wise et al. (1993) reported that the ability of macrophages to phagocytize virulent Edwardsiella ictaluri was enhanced by vit.E, but agglutinating antibody titers were not affected by dietary vit.E levels for channel catfish fingerlings fed with purified diets containing $\alpha$-tocopherol acetate to provide 0 , 60 and 2,500 mg vit.E/kg for 180 days. Verlhac et al. (1991) also concluded that vit.E deficiency impaired antibody response and lymphoproliferation. Conversely, Vani et al. (2011) reported that the total leukocyte count was significantly less $(P<0.05)$ in fish exposed to deltamethrin concentration of $1.61 \mu \mathrm{g} / \mathrm{l}$ and fed normal diet. The WBCs was significantly increased $(P<0.05)$ in fish exposed to 0.25 copperoxychloride level and fed diet supplemented with 1 and $2 \mathrm{~g}$ vit.E/ $\mathrm{kg}$ and recorded the value cope up treatment of zero fungicide.

Serum immunoglobulins are major components of the humoral immune system and IgM is the main immunoglobulin present in fish (Wilson et al. 1995). Our study revealed the significant decrease in IgM values in $O$. niloticus exposed to copperoxychloride fungicide chronic exposure (90 days). In full agreement with results of the effect of copperoxychloride level on IgM values, Hashim and Zaki (2005) reported that, in catfish exposed to fungicide Dithane in dose of $0.5 \mathrm{ppm} / 1$ (equivalent to $1 / 10$ of $\mathrm{LD}_{50}$ ) for 30 days, $\mathrm{IgM}$ in serum decreased significantly $(P<0.05)$ compared with control. Similarly, Giron et al. $(2009)$ reported that the IgM levels in plasma from Oreochromis niloticus exposed to $1 / 20 \mathrm{LC}_{50}(0.39)$ and $1 / 10 \mathrm{LC}_{50}(0.78) \mathrm{mg} / \mathrm{l}$ diazinon were not affected, but at $1.96 \mathrm{mg} / \mathrm{l}$ diazinon increased $\mathrm{IgM}$ concentrations for $96 \mathrm{~h}$ (short exposure) and also observed that fish could be exposed to concentrations of diazinon for long periods (chronic exposure) or in combination with another pesticide. Similarly, Martha et al. (2010) revealed that $O$. niloticus exposed to short sublethal $(7 \mathrm{ppb}, 96 \mathrm{~h})$ of insecticide endosulfan increased significantly $(P<0.05)$ secretion of IgM. The obtained results revealed that, $\operatorname{IgM}$ values were significantly increased $(P<0.05)$ in fish exposed to 0.25 $\mathrm{LC}_{50}$ copperoxychloride level and fed diet supplemented with 1 and $2 \mathrm{~g}$ vit.E/kg and recorded the value cope up treatment of zero fungicide. Ndoye et al. (1989) reported that only an overdose of vit.E improved the antibody production of rainbow trout. Waagbø et al. (1993) showed higher total antibody level in Atlantic salmon fed vit.E-supplemented diets, an opposite effect to the differences found as regards to specific antibodies. In this respect, Verlhac et al. (1991) observed that antibody titre against red mouth disease at 40 days after vaccination was higher for fish fed $450 \mathrm{mg}$ vitamin $\mathrm{E} \mathrm{kg} /$ diet as compared to those fed at $45 \mathrm{mg} / \mathrm{kg}$. However, the beneficial effect on stimulation was time dependent, and after 120 days of feeding no difference was observed. Also, Sahoo and Mukherjee (2002) reported that vitamins E and C increased specific immunity and reduced mortality only in immunocompromised fish and failed in healthy fish. Lall and Olivier (1991) recommended that higher dose of vitamin $\mathrm{E}(>2,000 \mathrm{mg} / \mathrm{kg})$ should not be used in studies on immune response of fish because of problems due to hypervitaminosis.

DNA damage has been proposed as useful parameter for assessing the genotoxic properties of environmental pollutants (Kohn 1983). Our results revealed that fish exposed to sublethal doses of copperoxychloride fungicide had significantly $(P<0.05)$ increased DNA damage. The present investigation is in agreement with 
the results obtained by Mahmoud (2006) who revealed that both agricultural and industrial water pollution caused an increase in the percentage of DNA fragmentation in Tilapia Zillii but the percentage of industrial pollution was higher than that of agriculture. Also, Vittoria et al. (2004) found that at the middle part of Gota harbor, which is chronically subjected to heavy chemical pollution, the viviparous eelpout (Zoarces viviparus) had a high level of DNA damage. Arabi (2004) studied the effect of metal ion contamination on the functional capacity of carp gill cells with antioxidant interactions in an in vitro study. The results obtained showed that copper and mercury could cause a high rate of DNA breaks (single stranded) in carp gill cell suspensions as a comet appearance and DNA fragmentation is frequent in metal ion contamination. Similarly, Chang et al. (2009) reported that, DNA damage in hemocytes and hepatopancreas cells of shrimp Litopenaeus vannamei increase after treatment with cadmium chloride $\left(\mathrm{CdCl}_{2}\right)$ compared with controls. They also indicated that $\mathrm{Cd}$ can induce oxidative stress and DNA damage in the shrimp L. vannamei. Moreover, the results also demonstrated that this parameter can be used as sensitive indicators of exposure to this genotoxicant.

Histology has been used as a test for evaluating toxic effects of water pollutants (Eifac 1983; Murthy 1986). Liver is responsible for the digestion, filtration and storage of glucose. It is considered as the principle organ of detoxification and good indicator of aquatic environmental pollution (Ahmed 2012). The liver was examined because it plays a primary role in the metabolism and excretion of xenobiotic compounds with morphological alterations occurring in some toxic conditions (Rocha and Monteiro 1999). Metals can either increase or decrease hepatic enzyme activities and can lead to histopathological hepatic changes, depending on the metal type and concentration, fish species, period of exposure and other factors (Paris-Palacios et al. 2000). The histological changes in fish liver are a highly sensitive and accurate way to assess the effect of xenobiotic compounds in field and experimental studies (Figueiredo-Fernandes 2007). In a previous study, the normal morphology of the liver Nile tilapia was uniform in appearance and dark red in color. Moreover, liver in normal histology was made up of hepatocytes which were polygonal cells with a central spherical nucleus and a densely stained nucleolus. These cells were arranged in branches separated by sinusoids (Figueiredo-Fernandes et al. 2006). The present study also demonstrates that the liver of control fish exhibits a normal appearance and structure with no pathological abnormalities. The hepatocytes present a homogenous cytoplasm and a large central or subcentral spherical nucleus, except some samples only showed fatty degeneration. However, fish exposed to copperoxychloride cleared severe hemorrhage in hepatic tissue; this alteration is in agreement with the results obtained by Figueiredo-Fernandes et al. (2007) for the same species exposed to waterborne copper. Several studies had shown a variety of changes in the liver of $O$. niloticus, resulting from exposure to different toxic chemicals (Visoottiviseth et al. 1999; Figueiredo-Fernandes et al. 2006). Moreover, it was also reported by several studies that chronic copper accumulation in the liver of fish causes hepatocyte lysis, cirrhosis and ultimately death (Pourahamad and O'Brien, 2000; Varanka et al. 2001; Păunescu et al. 2010). Osman et al. (2009) observed similar liver changes following the administration of copper sulfate by $O$. niloticus. On the other hand, fish exposed to copperoxychloride and fed diet supplemented with vit.E in present study showed decrease in the appearance of several liver alterations. Also, fish fed diet supplemented with vit.E and not treated with copperoxychloride showed no lesions of liver. These results are in agreement with those of Mahmoud (2009). Vitamin E deficiency could cause hepatic necrosis in fish (Idris and Hassan, 2002). Wahli et al. (1998) studied the effect of combinations of vitamin C and E on immune response and disease resistance and found increasing in macrophage oxidative burst activity in fish receiving both vitamins at high levels.

Gills participate in many important functions in fish, such as respiration, osmoregulation and excretion. They remain in close contact with the external environment, and particularly sensitive to changes in the water quality. Also they are considered the primary target of the contaminants (Mazon et al. 2002). In the present study, histological examination of $O$. niloticus gills shows a typical structural organization of the lamellae in fish fed normal level, 1 and $2 \mathrm{~g}$ vit.E/kg diet and not exposed to copperoxychloride; some samples showed cell degeneration in secondary lamellae. However, fish exposed to copperoxychloride show several histological alterations, namely hemorrhage in primary lamellae and separation in secondary lamellae. These observations are in agreement with those obtained by Figueiredo-Fernandes et al. (2007) on the same species of fish with exposure of copper metals. These histological alterations of gill have been observed also by several authors in fish and shellfish submitted to copper (Karan et al. 1998; Chen and Lin 2001; De Boeck et al. 2001). Fish exposed to copperoxychloride and $1 \mathrm{~g}$ vit.E showed necrosis and curling in secondary lamellae, while those exposed to copperoxychloride and $2 \mathrm{~g}$ vit.E cleared separation in secondary lamellae. In the present study, the observed histological alterations of gill and liver have been related to copperoxychloride exposure. 


\section{Conclusion}

The exposure of $O$. niloticus to sublethal concentration of copperoxychloride caused alterations in growth, blood parameters, DNA fragmentation and histology. These alterations were reversed to a great extent with supplement of higher dose of vitamin $\mathrm{E}$ in diets. We recommended that cultured fish will be protected against any possible pesticide or fungicide stress using natural antioxidants such as vitamin $\mathrm{E}$ by supplemented it with higher level than it is normally required in the fish diet.

Acknowledgments The financial support provided by National Institute of Oceanography and fisheries Cairo, Egypt, (NIOF), for our Aquaculture division is greatly acknowledged.

Authors' contributions $\mathrm{MH}$ carried out the molecular genetic studies, participated in the sequence alignment, and drafted the manuscript,carried out the immunoassays and design the study and performed the statical analysis. AG conceived of the studyand participated in its design and coordination. SM and ST carried out the histology study. All authors read andapproved the final manuscript.

Open Access This article is distributed under the terms of the Creative Commons Attribution License which permits any use, distribution, and reproduction in any medium, provided the original author(s) and the source are credited.

\section{References}

Abdel-Tawab AA (1999) Environmental and nutritional studies on fish farms in El-Fayoum Governorate, Ph.D. Thesis, Environmental Studies and Research Institute, Ain Shams University, Cairo, Egypt

Abdel-Tawwab M, Mousa MA, Ahmed MH, Sakr SF (2007) The use of calcium (Ca) pre-exposure as a protective agent against environmental copper toxicity for juvenile Nile tilapia, (Oreochromis niloticus L). Aquaculture 264:236-246

Ahmed NA (2012) Biochemical studies on pollution of the River Nile at different stations of delta barrage (Egypt). Ph.D. thesis. Fac. of Agric. Benha,Univ

Alam MK, Maughan OE (1992) The effect of malathion, diazinon and various concentrations of zinc, copper, nickel, lead, iron and mercury on fish. Biol Trace Elem Res 34:225-236

Arabi M (2004) Metal ion-mediated oxidative stress is associated with increased cell membrane and DNA damage in carp gill suspensions. Section 5: Caspian Sea, Ecology and Biology

Association of Official Analysis Chemists, AOAC (1990) Official methods of analysis. 12th edn. Washington D.C.

Bagheri F (2007) Study of pesticide residues (Diazinon, Azinphosmethyl) in the rivers of Golestan province (GorganRoud and Gharehsou), M.Sc. Thesis, Tehran University of Medical Science. Tehran, Iran, 1-125

Bernet D, Schmidt H, Meier W, Burkhardt-Olm P, Wahi T (1999) Histopathology in fish: proposal for a protocol to assess aquatic pollution. J Fish Dis 22:25-34

Boyd CE (1984) Water Quality in Warm Water Fishponds. Auburn University Agriculture Experimental Station Auburn Alabama USA

Brett JR (1973) Energy expenditure of Sockeye salmon Oncorhynchus nerka, during sustained performance. J Fish Res Board Can 30:1799-1809

Chang M, Wang WN, Wang AL, Tian TT, Wang P, Zheng Y, Liu Y (2009) Effects of cadmium on respiratory burst, intracellular $\mathrm{Ca}^{2+}$ and DNA damage in the white shrimp Litopenaeus vannamei. Comp Biochem Physiol Part C 149:581-586

Chen JC, Lin CH (2001) Toxicity of copper sulfate for survival, growth, molting and feeding of juveniles of the tiger shrimp, Penaeus monodon. Aquaculture 192:55-65

Crane M, Maltby L (1991) The lethal and sublethal responses of Gammarus pulex to stress: sensitivity and sources of variation in an in situ bioassay. Environ Toxicol Chem 10:1331-1339

De Boeck G, Vlaeminck A, Balm PH, Lock RA, De Wachter B, Blust R (2001) Morphological and metabolic changes in common carp (Cyprinus carpio) during short-term copper exposure: interactions between $\mathrm{Cu}^{2+}$ and plasma cortisol elevation. Environ Toxicol Chem 20:374-381

Duncan MB (1955) Multiple ranges and multiple F-tests. Biometrics 11:1-42

Eifac (1983) European Inland Fisheries Advisory Commission 1983. Working party on toxic testing procedures, Revised report on fish toxicity testing procedures. Eifac tech paper (24) Rev. 1:37

El-Ezaby MM (1994) Certain studies on the effect of some pollutants on freshwater fish. Ph.D. Thesis Fac Sci Benha, Univ

Fernández-Calviño D, Nóvoa-Muñoz JC, López-Periago E, Arias-Estévez M (2008) Changes in copper content and distribution in young, old and abandoned vineyard acid soils due to land use changes. Land Degrad Dev 19(2):165-177

Figueiredo-Fernandes A, Monteiro RAF, Reis-Henriques MA, Rocha E (2006) Effects of the fungicide mancozeb in the liver structure of Nile tilapia (Oreochromis niloticus) Assessment and quantification of induced cytological changes using qualitative histopathology and the stereological point-sampled intercept method. Bull Environ Contam Toxicol 76(2):249-255

Figueiredo-Fernandes A, Fontaínhas-Fernandes A, Cardoso JV, Garcia-Santos S, Monteiro SM, Carola J, Matos P, Fernades A (2007) Histopathological change in liver and gills epithelium of Nile tilapia (Oreochromis niloticus) exposed to waterborne copper. Pesquia Vetrinaria Brasileira 27:103-109

Furones MD, Alderman DJ, Bucke D, Fletcher TC, Knox D, White A (1992) Dietary vitamin E and the response of rainbow trout, Oncorhynchus mykiss (Walbaum), to infection with Yersinia ruckeri. J Fish Biol 41:1037-1041 
Galaz GB, Kim SS, Lee KJ (2010) Effects of different dietary vitamin E levels on growth performance, non-specific immune responses, and disease resistance against Vibrio anguillarum in Parrot fish, Oplegnathus fasciatus. Asian Aust J Anim Sci 23(7):916-923

Giron PMI, Velazquez FJ, Diaz RK, Diaz F, Salas C, Montero C, Medina DI, Robledo MM, Rojas GA, Zaitseva G (2009) Immunologic parameters evaluations in Nile tilapia Oreochromis niloticus exposed to sublethal concentrations of diazinon. Fish Shellfish Immunol 27:383-385

Hamre K, Berge RK, Lie O (1998) Turnover of alpha tocopherol, gamma tocopherol and delta tocopherol and distribution in sub cellular and lipoprotein fractions indicate presence of an hepatic tocopherol binding protein in Atlantic salmon (Salmo salar L.). Fish Physiol Biochem 18:71-83

Hashim EF, Zaki MS (2005) Assessment of the hazardous effect of fungicide Dithane on (Clarias lazera) catfish including haematological, biochemical and immunological parameters. Arab Univ J Agric Sci 13(3):1005-1018

Henry RJ (1974) Clinical chemistry principles and techniques, 2nd edn. Harper and Row Publ, New York 525

Holladay SD, Smith SA, El-Habback H, Caceci T (1996) Influence of chlorpyrifos, an organophosphate insecticide on the immune system of Nile tilapia. J Aquat Anim Health 8:104-110

Idris A, Hassan AA (2002) A review of medical biochemistry. Bioch. Dept., Fac. Med., Zagazig, Univ 1-263

Jenkins F, Smith J, Rajanna B, Shameem U, Umadevi K, Sandhya V, Madhavi R (2003) Effect of sub lethal concentration of endosulfan on hematological and serum biochemical parameters in the carp, (Cyprinus carpio). Bull Environ Contam Toxicol 70:993-997

Jiraungkoorskul W, Upatham ES, Kruatrachue M, Shaphong S, Vichasri-Grams S, Pokethitiyook P (2003) Biochemical and histological animals effect of glyphosate herbicide on Nile tilapia (Oreochromis niloticus). Environ Toxicol 18:260-267

Karan V, Vitorovic S, Tutundzic V, Poleksic V (1998) Functional enzymes activity and gill histology of carp after copper sulfate exposure and recovery. Ecotoxicol Environ Safety 40:49-55

Khoshbavar-Rostami HA, Soltani M, Hassan HMD (2006) Immune response of great sturgeon (Huso huso) subjected to long-term exposure to sub-lethal concentration of the organophosphate, diazinon. Aquaculture 256:88-94

Kim KW, Wang X, Choi SM, Park GJ, Koo JW, Bai SC (2003) No synergistic effects by the dietary supplementation of ascorbic acid, $\boldsymbol{\alpha}$-tochopheryl and challenge test of Edwardsiella tarda in fingerling Nile tilapia (Oreochromis niloticus L.). Aquac Res 34:1053-1058

Kohn HW (1983) The significance of DNA damage assays in toxicity and carcinogenicity assessment. Ann NY Acad Sci 407:106-118

Komárek M, Vaněk A, Chrastný V, Száková J, Kubová K, Drahota P, Balík J (2009) Retention of copper originating from different fungicides in contrasting soil types. J Hazard Mater 166:1395-1402

Lall SP, Olivier G (1991) Role of micronutrients in immune response and disease resistance of fish. In: Kaushik SJ, Luquet P (eds) Fish Nutrition in Practice. IV International Symposium on Fish Nutrition and Feeding 24-27 June 1991 Biarritz France. INRA, Paris, pp 101-118

Li MH, Johnson MR, Robinson EH (1993) Elevated dietary vitamin C concentrations did not improve resistance of channel catfish (Ictalurus punctatus) against Edwardsiella ictaluri infection. Aquaculture 117:303-312

Mahmoud AA (2006) Effect of water pollution on genetic structure of fresh water fish in Qalubia Governorate. Ph.D. thesis faculty of science Benha University

Mahmoud SA (2009) Effect of different artificial diets on the growth rate condition and histological structure of Nile tilapia (Oreochromis niloticus). J Fish Hydrobiol 4(1):29-34

Maita M, Shiomitsu L, Ikeda Y (1984) Health assessment by the climogam of hemochemical constituents in cultured yellow tail. Bull Jpn Soc 51:205-211

Martha CT, Anne S, Josefina CS, Galina Z (2010) Endosulfan increasing seric interleukin-2 like (IL-2L) factor and immunoglobulin M (IgM) of Nile tilapia (Oreochromis niloticus) challenged with Aeromona hydrophila. Fish Shellfish Immunol 28:401-405

Martins ML, Nomura DT, Myiazaki D, Pilarsky F, Ribeiro K, Castro MP (2004) Physiological and hematological response of Oreochromis niloticus (Osteichthyes: Cichlidae) exposed to single and consecutive stress of capture. Acta Sci Anim Sci 26:449-456

Maxine M, Benjamine BS (1985) Outline of veterinary clinical pathology, 8th edn, Colorado State University Printed in India at Rekha Printers PVT.LTD. New Delhi 110020

Mazon AF, Cerqueira CC, Fernandes MN (2002) Gill cellular changes induced by copper exposure in the South American tropical freshwater fish (Prochilodus scrofa). Environ Res 88:52-63

Metwally MAA, Ali MA, El-Sayed AMS, Salah ME (2002) Biochemical effect of different concentrations of vitamin E and selenium on copper toxicity in tilapia (Oreochromis niloticus). In: The 1st scientific conference on Aquaculture organized by the Egyptian aquaculture society and Uni. of Suez Canal 13-15 December, 2002 El-Arish 13-15 Dec., pp 401-409

Miren P, Cajaraville MJ, Bebianno JB, Cinta P, Carmen S, Aldo V (2000) The use of biomarkers to assess the impact of pollution in coastal environments of the Iberian peninsula: a practical approach. Sci Total Environ 247:295-311

Mourente G, Diaz E, Bell J, Tocher D (2002) Increased activities of hepatic antioxidant defense enzymes in juvenile gilthead sea bream (Sparus aurata L) fed dietary oxidized oil: attenuation by dietary vitamin E. Aquaculture 214(1-4):343-361

Mousa MAA, Mohamed SF, Saleh FMS (2005) Assessment of the counteracting effect of selenium on the toxicity of basagran herbicide to Oreochromis niloticus. J Egypt Acad Soc Environ Dev (B-aquaculture) 6 (1):133-157

Murthy AS (1986) Toxicity of pesticide to fish. CRC Press Inc. Boca Raton, p 143

National Research Council NRC (1993) Nutrient requirements of fish. National Academy Press, Washington D. C.

Ndoye A, Ghanmi Z, Koenig J, Deschaux P (1989) Vitamin E and immunity: effects of vitamin E on the production of antiYersinia ruckeri antibodies in rainbow trout (Salmo gairdneri). Ichtyophysiologica Acta 13:17-23 
Osman MM, El-Fiky SA, Soheir YM, Abur AT (2009) Impact of water pollution on histopathological and electrophoretic characters of Oreochromis niloticus fish. Res J Environ Toxicol 3(1):9-23

Paris-Palacios S, Biagianti-Risbourg S, Vernet G (2000) Biochemical and (ultra) structural hepatic perturbation of Brachydanio rerio (Teleostei: Cyprinidae) exposed to two sublethal concentrations of copper sulphate. Aquat Toxicol 50:109-124

Păunescu A, Ponepal CM, Drăghici O, Marinescu AG (2010) Histopathological responses of the liver tissues of Rana ridibunda to the champions $50 \mathrm{wp}$ fungicide. Ann Food Sci Technol 11:60-64

Pernadones CE, Illera VA, Peckham D, Stunz LL, Ashman RF (1993) Regulation of apoptosis in vitro in mature murine spleen T cells. J Immunol 151(7):3521

Pourahamad J, O'Brien PJ (2000) A comparison of hepatocyte cytotoxic mechanisms for $\mathrm{Cu}^{2+}$ and $\mathrm{Cd}^{2+}$. Toxicol 143:263-273

Ramzy EM (2009) Study the exposure effect of insecticide profenofoes (selecoron) on physiological responses of Nile tilapia (Oreochromis niloticus). Ph.D. Thesis Science Zoology Benha University

Reish DL, Oshida PA (1987) Manual of methods in aquatic environment research Part 10, Short-term static bioassay, FAO Fisheries Technical Paper 247. FAO Rome, pp 1-62

Reitman S, Frankel S (1957) Colorimetric determination of glutamic oxaloacetic and glutamic pyruvic transaminases. J Clin Pathol 28:56-59

Rendon-von Osten J, Ortiz-Arana A, Guilhermino L, Soares AM (2005) In vivo evaluation of three biomarkers in the mosquito fish (Gambusia yucatana) exposed to pesticides. Chemosphere 58:627-636

Rocha E, Monteiro RAF (1999) Histology and cytology of fish liver: a review. In: Ia DN (ed) Ichthology Recent research advances. Science Publishers, Enfield, pp 321-344

Sahoo PK, Mukherjee SC (2002) The effect of dietary immunomodulation upon Edwardsiella tarda vaccination in healthy and immunocompromised Indian major carp (Labeo rohita). Fish Shellfish Immunol 12:1-16

Sau SK, Paul BN, Mohanta KN, Mohanty SN (2004) Dietary vitamin E requirement, fish performance and carcass composition of rohu (Labeo rohita) fry. Aquaculture 240:359-368

Senug H, Min-Won B, Hui-Young L, Dong-Jae K, Yi-Rang N, Kyoung N, Song P, Hyan K, Byoung H, Dong R, Jae-Hak P (2007) Arsenite-induced apoptosis is prevented by antioxidants in zebra fish liver cell line. Toxicol In Vitro 21(5):870-877

Soltan M, Hanafy A, Soltan MA, Wafa MI (2008) Effect of replacing fish meal by a mixture of different plant protein sources in Nile tilapia (Oreochromis niloticus L.) diets. Global Vet 2(4):157-164

Statistical Analysis System (SAS) (1993) SAS/STAT user Guide Release. 6.03 edn. SAS Institute Inc, Cary

Steven C (2002) Understanding fish nutrition, feeds and feeding. Virginia Corp, Richmond, pp 420-456

Svobodova Z, Luskova V, Drastichova J, Svoboda M, Zlabek V (2003) Effect of deltamethrin on haematological indices of common carp (Cyprinus carpio L.). Acta Vet Brno 72:79-85

Sweilum MA (2000) Effect of different percentages of sewage water on growth performance, survival rate and feed conversion ratio of Nile tilapia (Oreochromis niloticus). Vet Med J 48:179-184

Sweilum MA (2006) Effect of sublethal toxicity of some pesticides on growth parameters, haematological properties and total production of Nile tilapia (Oreochromis niloticus L.) and water quality of ponds. Aquac Res 37:1079-1089

Thrall MA (2004) Veterinary hematology and clinical chemistry. Williams and Wilkins, Philadelphia, pp 277-289

Tripathi PK, Srivastava VK, Singh A (2003) Toxic effects of dimethoate (organophosphate) on metabolism and enzyme system of freshwater teleost fish Channa punctatus. Asian Fish Sci 16:349-359

Vani T, Saharan N, Mukherjee SC, Ranjan R, Kumar R, Brahmchari RK (2011) Deltamethrin induced alterations of hematological and biochemical parameters in fingerlings of Catla catla (Ham.) and their amelioration by dietary supplement of vitamin C. Pestic Biochem Physiol 101(1):16-20

Varanka Z, Rojik I, Varanka I, Nemcsók J, Ábrahám M (2001) Biochemical and morphological changes in carp (Cyprinus carpio L.) liver following exposure to copper sulfate and tannic acid. Comp Biochem Physiol 128:467-478

Verlhac V, Doye AN, Gabaudan J, Troutaud D, Deschaux P (1991) Vitamin nutrition and fish immunity: influence of antioxidant vitamins (C and E) on immune response of rainbow trout. In: Kaushik SJ, Luquet P (eds) Fish Nutrition in Practice. IV International Symposium on Fish Nutrition and Feeding, 24-27 June Biarritz France. INRA, Paris pp 167-177

Visoottiviseth P, Thamamaruitkun T, Sahaphong S, Riengrojpitak S, Kruatrachue M (1999) Histopathological effects of triphenyltin hydroxide on liver, kidney and gill of Nile tilapia (Oreochromis nilotica). Appl Organometal Chem 13:749-763

Vittoria S, Ilaria DB, Joachim S (2004) DNA damage in eelpout (Zoarces Viviparous) from Goteborg harbor. Mutat Res 552:187-195

Vryzas Z, Vassiliou G, Alexoudis C, Papadopoulou-Mourkidou E (2009) Spatial and temporal distribution of pesticide residues in surface waters in northeastern Greece. Water Res 43:1-10

Waagbø R, Sandnes K, Lie Ø, Nilsen ER (1993) Health aspects of dietary lipid sources and vitamin E in Atlantic salmon (Salmo salar). I. Erythrocyte total lipid fatty acid composition, haematology and humoral immune response. Fiskidir Skr Ser Ernaer 6:47-61

Wahli T, Verlhac V, Gabaudan J, Schuep W, Meier W (1998) Influence of combined vitamins C and E on non-specific immunity and disease resistance of rainbow trout, Oncorhynchus mykiss (Walbaum). J Fish Dis 21:127-137

Wilson JM, Laurent P (2002) Fish gill morphology: inside out. J Exp Zool 293:192-213

Wilson MR, Van Ravenstein E, Miller NW, Clem LW, Middleton DL, Warr GW (1995) cDNA sequences and organization of IgM heavy chain genes in two holostean fish. Dev Comp Immunol 19:153-164

Wise DJ, Tomasso JR, Schwedler TE, Blazer VS, Gatlin DM (1993) Effect of vitamin E on the immune response of channel catfish to Edwardsiella ictaluri. J Aquat Anim Health 5:183-188

Zar JH (1984) Biostatistical analysis. Prentice-Hall, Englewood Cliff 